Gynec. Invest. 1970;1:I-VII

\title{
Contents, Vol. 1, 1970
}

\section{Contents}

Herrmann, W.L. and Heinrichs, W.L.: Who Needs a New Journal?

Mikhail, G.: Hormone Secretion by the Human Ovaries

Klebanoff, S.J. and Smith, D.C.: Peroxidase-mediated Antimicrobial Activity of Rat Uterine Fluid 21

Hayashi, T.T. and Kazmierowski, Dolores: Placental and Fetal RNA Metab olism. I. In vivo Labeling of the Fetal and Placental RNA in the 14-day Pregnant Rat 31

Chez, R.A.: Ion Transport by the Primate Neonatal Stomach

Nakamura, R.M.; Theppisai, H.; Okada, D.M. and Mishell, D.R., Jr.: Immunoassay of HPL by Complement Fixation 46

Lefèbvre, Y.; Chapdelaine, A. and Bolté, E.: Effects of Labor on Plasma

Dehydroepiandrosterone Sulfate and Cortisol 57

Lindheimer, M.D.: Further Characterization of the Influence of Supine Pos ture on Renal Function in Late Pregnancy. Effect of Rapid Saline Infusions on Renal Sodium, Water and Uric Acid Metabolism

Martin, J.E.; Ware, R.W.; Crosby, R.J. and Pauerstein, C.J.: Demonstration of Beta Adrenergic Receptors in the Rabbit Oviduct 82

Neuman, M.R.; Picconnatto, J. and Roux, J.F.: A Wireless Radiotelemetry System for Monitoring Fetal Heart Rate and Intrauterine Pressure During Labor and Delivery 92

Misenhimer, H.R. and Ramsey, Elizabeth M.: The Effect of Anesthesia and Surgery in Pregnant Rhesus Monkeys 105

Brinkman, C.R., III; Kirschbatjm, T.H. and Assali, N.S.: The Role of the Umbilical Sinus in the Regulation of Placental Vascular Resistance 115 Gellert, R.J.; Bakke, J.L. and Lawrence, Nancy: Modification of Pituitary Thyrotropin and Thyroid Activity in the Rat Following Administra tion of Clomiphene Citrate 129

Scott, J.R.; Anderson, W.R.; Kling, T.G. and Yannone, M.E.: Uterine Transplantation in Dogs 140

Vanha-Perttula, T.; Schneider, G; Bardin, C.W.; Stanley, A.J.; Gumbreck, L.G. and Allison, J.E.: Testicuiar Tumors in the Androgen Insen sitive Pseudohermaphrodite Rat: Histochemistry and Steroid Metab olism 149

Zijlstra, J.B.; Torringa, J.L. and Bouma, J.M.W.: Intracellular Distribution of Alkaline Phosphatase in Human Placenta 161

Jaffe, R.B.; Midgley, A.R., Jr.; Goebelsmann, U. and Snyder, D.L.: Regula tion of Human Gonadotropins. IX. Effects of Administration of Low-Dose Chlormadinone Acetate upon Serum Luteinizing Hor 
mone, Follicle Stimulating Hormone, Progesterone and Urinary

Pregnanediol 169

VI

Contents

Page, E.W.: The Society for Gynecologic Investigation

179

Nesbitt, R.E.L., Jr.; Rice, P.A.; Rourke, J.E.; Torresi, V.F. and Souchay, A.M.: In vitro Perfusion Studies of the Human Placenta. A NewlyDesigned Apparatus for Extracorporeal Perfusion Achieving Dual Closed Circulation 185

Dyer, D.C.: Comparison of the Constricting Actions Produced by Serotonin and Prostaglandins on Isolated Sheep Umbilical Arteries and Veins 204

Josimovich, J.B.; Wilson, E.L. and Leff, A. (With the technical assistance of Hays, B. and Boccella, L.): Vaginal Mucification Induced by Pitu itary Prolactin and Placental Lactogen in Mice. A Luteotrophic Test for Protein Hormone Preparations 210

Goebelsmann, U. and Work, B.A., Jr.: Estriol Conjugates in Amniotic Fluid in Normal Pregnancies and Rh-isoimmunization 222

Wiegershausen, B.; Klausch, B.; Hennighausen, G.; Paegelow, I. and

Raspe, R.: Content of Kininogen and Activity of Kininase in the

Amniotic Fluid in the Various Periods of Pregnancy 234

Ogawa, Y.; Herod, L. and Lanman, J.T.: Phospholipids and the Onset of

Labor in Rabbits 240

Carr, M.C.: Study into the Mechanisms of Damage of Human Placental

Syncytiotrophoblast. I. The Effect of Maternal Intrapartum Plasma 249

Pauersteyn, C.J.; Fremming, B.D. and Martin, J.E.: Influence of Progesterone and Alpha

Adrenergic Blockade upon Tubal Transport of Ova 257

Huisjes, H.J. and Wobbes, Th.: The Latex Agglutination Test Applied to

Liquor Amnii 268

Wobbes, Th. and Huisjes, H.J.: The Nature of a Latex-Reacting Compound in

Amniotic Fluid 272

Aleem, F.A.; Vald $\gamma$ via, E. and Colas, A.E.: The Aromatizing Activity of

Placental Mitochondrial and Microsomal Fractions 277

Braaksma, J.T.; Janssens, J.; Eskes, T.K.A.B.; Arp, A. and Hein, P.R: Accu

rate Pressure Recording in the Non-Pregnant Human Uterus 288

Martin, J.E.; McGuyre, W.L. and Pauerstein, C.J.: Macromolecular Binding

of Estradiol in the Rabbit Oviduct and Uterus 303

Chez, R.A.; Josimovich, J.B. and Schultz, S.G.: The Transfer of Human

Placental Lactogen across Isolated Amnion-Chorion 312

Sadovsky, E.; Pfeifer, Y.; Polishuk, W.Z. and Sulman, F.G.: The Value of

Progesterone Derivatives in Prevention of Serotonin Abortion in Rats 319

Betz, G. and Susee, P.: The Effect of Mercury Estradiol on 17/?-Estradiol

Dehydrogenase 327

Jaffe, R.B.: Estriol in High-risk Pregnancies: Has it Kept its Promise? .. $\quad$ Suppl. 1

Heinrichs, W.L.; Soderstrom, R.; Jaffe, R.B.; Vande Wiele, R.L.;

Ueland, K. and Plant, R.: Panel Discussion

Suppl. 7

Bowe, E.T.: Treatment and Prophylaxis of Rh Disease

Suppl. 13 
Johnson, W.L.; Bowe, E.T.; Quilligan, E.J.; Giblett, E.; Gorman, J.; Depp, R. and Jaffe, R.B.: Panel Discussion Suppl. 20

VII

Quilligan, E.J.: Keeping a Finger on the Fetal Pulse

Suppl. 26

Smith, D.C; Quilligan, E.J.; Johnson, W.L.; Thiele, R.; Hendricks,

Ch.H.; Polley, R. and Rollins, P.: Panel Discussion

Suppl. 32

Hendricks, Ch.H.: The Control of Labor

Suppl. 37

Hunter, C.A., Jr.; Hendricks, C.H.; Quint, B.C.; Bowe, E.T. and John

son, W.L.: Panel Discussion Suppl. 52

Vande Wiele, R.L.: Steroid Contraceptives Suppl. 55

Herrmann, W.L.; Keifer, W. and Vande Wiele, R.L.: Panel Discussion Suppl.67

Proceedings

Forum of Modern Obstrical Practice. Edited by W.L. Herrmann and

W.L. Hernichs Suppl. 1

To the Members of the Society of Gynecologic Investigation .. 182

Announcements

News $\quad 128,332$

Subject Index 333

Authors' Index 